\title{
Usporedba dinamičke stabilnosti nogometaša i rukometaša
}

IIIIIIIIIIIIIIIIIIIIIIIIIIIIIIIIIIIIIIIIIIIIIIIIIIIIIIIIIIIIIIIIIIIIIIIIIIIIIIIIIIIIIIIIIIIIIIIII

1 Ines Pinter

2 Dalibor Kiseljak

2 Olivera Petrak

1 Nia physio, Bjelovar

2 Zdravstveno veleučilište Zagreb

\section{Sažetak}

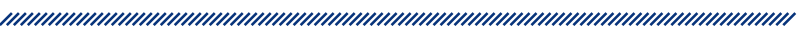

Kako bi sportaš proveo trening visokog intenziteta, mora imati dobru posturu, ravnotežu, ravnomjerno razvijenu jakost i fleksibilnost mišića lijeve i desne te prednje i stražnje strane tijela, odnosno mora imati dobru stabilnost i mobilnost.

Cilj je istraživanja usporediti dinamičku stabilnost nogometaša i rukometaša primjenom metode procjene Functional Movement Screening (FMS) koja se sastoji od sedam testova kojima se dijagnosticiraju ograničenja u mobilnosti i stabilnosti te različite asimetrije, a smatra se pouzdanim prediktorom rizika za ozljeđivanje. Cilj je također uvidjeti postoji li razlika u rezultatima FMS testova prema dobnom rangu općenito, kao i u pojedinom sportu. Zanimalo nas je i provjeriti postoji li povezanost između dobi i indeksa tjelesne mase (ITM) sudionika s dinamičkom stabilnošću izraženom kao ukupni FMS rezultat.

Istraživanje je provedeno u NK-u Bjelovar i RK-u Bjelovar, na uzorku od 51 sudionika prosječne dobi 20,27 godina (raspon 16 - 33), tjelesne visine 183,01 cm (171 - 195), tjelesne mase $80,42 \mathrm{~kg}(60$ - 132). Uzorak čini 30 nogometaša (17 juniora i 13 seniora) te 21 rukometaš (osam juniora i 13 seniora).
Jedina značajna razlika u FMS-u između nogometaša i rukometaša pokazala se za test iskoraka na liniji, u kojem nogometaši postižu bolji rezultat. Usporedbom dviju dobnih kategorija nogometaša odnosno rukometaša razlika se nije pokazala značajnom ni u jednom FMS testu. ANOVA pokazuje postojanje značajne razlike između rukometaša seniora i nogometaša juniora u podtestovima prekoraka i iskoraka na liniji.

Između dobi i ukupnog FMS rezultata nema značajne korelacije, ali je test mobilnosti ramena značajno negativno povezan s dobi. S ITM-om su značajno negativno povezani ukupni rezultat na FMS testu te rezultati na testu dubokog čučnja i mobilnosti ramena, no te su korelacije relativno niske.

Nogometaši i rukometaši ne pripadaju skupini s povećanim rizikom za ozljeđivanje. FMS se preporučuje kao instrument procjene dinamičke stabilnosti jer je pouzdan, osjetljiv i jednostavan za primjenu.

Ključne riječi: FMS, stabilnost, mobilnost, nogomet, rukomet

Datum primitka: 22.02.2018.

Datum prihvaćanja: 15.03.2018.

DOI: $10.24141 / 1 / 4 / 1 / 4$

Adresa za dopisivanje:

Dalibor Kiseljak

Zdravstveno veleučilište Zagreb

Mlinarska cesta 38, 10000 Zagreb

Tel.: +385915495736

E-pošta:dalibor.kiseljak@zvu.hr 


\section{Uvod}

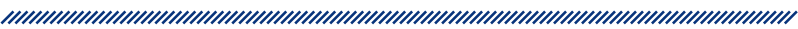

Pred sportaše se u današnje vrijeme postavljaju visoki ciljevi koji od njih zahtijevaju optimalnu razinu pripremljenosti. Kako bi sportaš bio spreman za tjelesne napore tijekom trenažnog i natjecateljskog procesa, mora imati dobru posturu, ravnotežu, ravnomjerno razvijenu jakost i fleksibilnost mišića lijeve i desne te prednje i stražnje strane tijela, odnosno mora imati dobru stabilnost i mobilnost. lako se nogomet i rukomet poprilično razlikuju u načinu igre, oba sporta pripadaju skupini momčadskih sportova te zahtijevaju visoku razinu tjelesne pripremljenosti sportaša.

Mobilnost je sposobnost izvođenja odgovarajućeg opsega pokreta u pojedinom zglobu, dok je stabilnost sposobnost kontrole jakosti i snage, odnosno sposobnost odupiranja neželjenim silama i pokretima ${ }^{1}$. Mobilnost i stabilnost mogu se opisati kao temeljni građevni blokovi brzine, snage, jakosti, izdržljivosti i agilnosti. Ako navedeni blokovi nisu na mjestu, sportaš će razviti biomehanički insuficijentne kretnje te time ograničiti razvoj vlastitih motoričkih i funkcionalnih sposobnosti. Također, njegovo će tijelo početi razvijati kompenzatorne pokrete, čime dolazi do povećanog rizika od ozljede te smanjene kvalitete izvedbe sportske aktivnosti².

Pokret je od vitalne važnosti za osobu te je važnija kretnja čovjekova tijela kao cjeline, što će mu omogućiti dolazak do željenog cilja, nego zbroj pojedinačnih kretnji u svakome segmentu. Funkcionalna interakcija između struktura znatno utječe na izvedbu pokreta ${ }^{3}$. Sahrmann ${ }^{4}$ smatra kako bi svaki fizioterapeut trebao detaljnije opservirati i analizirati pokret te procjenjivati funkcionalne aktivnosti pojedinca, neovisno o području fizioterapije kojim se bavi.

Stabilnost i mobilnost odnosno dinamička stabilnost procjenjuju se različitim testovima, a sve se češće kao metoda procjene primjenjuje funkcionalna procjena pokreta Functional Movement Screening (FMS), sačinjena od sedam testova kojima se procjenjuje ispitanikova stabilnost i mobilnost. Također se procjenjuje postojanje asimetrija lijeve i desne strane tijela. Kako bi tijelo učinkovito funkcioniralo kao cjelina, svaki mišić i zglobni sustav u njemu mora obavljati svoju temeljnu funkciju. S obzirom na to da ljudsko tijelo nije skup nezavisnih segmenata, već su oni međusobno povezani i ovise jedni o drugima, pogotovo kad je riječ o lokomotornom sustavu, FMS testovi mogu pružiti objektivne podatke o kvaliteti ispitanikovih obrazaca pokreta. Zbog povezanosti segmenata lokomotornog sustava, čak i njegovih najmanjih dijelova, često se događa da problem nije na mjestu boli, već je bolno mjesto posljedica disbalansa u stabilnosti ili mobilnosti drugog segmenta odnosno dijela tijela. Prilikom testiranja moguće je prepoznati slabije karike u ljudskom tijelu te mjesta smanjene mobilnosti i/ili stabilnosti te tako ustanoviti potencijalne izvore problema. FMS se najčešće primjenjuje kod vrhunskih sportaša, no može ga upotrebljavati i opća populacija, a testovi služe i kao vježbe prevencije te poboljšanja sportske izvedbe ${ }^{1}$. Cook i suradnici ${ }^{5}$ navode kako nepravilnosti u biomehanici lokomotornog sustava te nepravilno izvođenje fundamentalnih pokreta mogu imati negativan utjecaj na sportaševu izvedbu te povećati rizik od ozljede. Cook i suradnici ${ }^{6}$ ukazuju kako je FMS važan za analizu funkcionalnih pokreta te kako se može primijeniti na kraju rehabilitacijskog procesa, ali i početkom novih tjelesnih napora. Prema tome, rezultati dobiveni ovim specifičnim testiranjem mogu ukazivati na povećanu ili smanjenu mogućnost ozljeđivanja.

FMS se preporučuje kao instrument procjene dinamičke stabilnosti jer je pouzdan, osjetljiv i jednostavan za primjenu ${ }^{7}$. $U$ istraživanju Minicka i suradnika ${ }^{8}$ nije se pokazala razlika u ocjenjivanju kod iskusnih ispitivača i studenata koji su ukratko podučeni načinu ocjenjivanja i procjene. Teyhen i suradnici ${ }^{9}$ utvrdili su u dobru pouzdanost FMS testa i retesta istih ispitivača, kao i različitih ispitivača u simultanoj procjeni sudionika. Smith i suradnici ${ }^{10}$ također su utvrdili da FMS može biti pouzdan test mjerenja bez obzira na iskustvo ispitivača, ali uz dva sata prethodne edukacije te provođenje nekoliko testiranja.

Cilj je istraživanja s pomoću FMS testiranja uvidjeti postoji li razlika u dinamičkoj stabilnosti nogometaša i rukometaša te ispitati postoji li razlika u rezultatima podtestova FMS-a između dvije uzrasne kategorije, seniora i juniora, za svaki sport, kao i općenito. Namjera je i provjeriti postoji li povezanost dobi ispitanika kao i njihova indeksa tjelesne mase (ITM), s rezultatom procjene dinamičke stabilnosti, odnosno ukupnog rezultata FMS-a. Konačno, zanimalo nas je imaju li promatrane skupine značajan rizik za ozljedu.

Pretpostavka je istraživanja da postoji značajna razlika u dinamičkoj stabilnosti nogometaša i rukometaša, kao i da postoji razlika u rezultatima podtestova FMSa između nogometaša juniorske i seniorske kategorije te između rukometaša juniorske i seniorske kategorije. Očekuje se niska korelacija dobi i ITM-a sudionika s rezultatom procjene dinamičke stabilnosti. Pretpostavljamo da sudionici nisu u riziku od ozljede. 


\section{Metode}

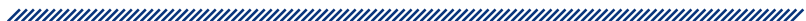

\subsection{Sudionici}

Sudionici su igrači Nogometnog kluba Bjelovar te Rukometnog kluba Bjelovar, koji se natječu u hrvatskim nacionalnim ligama, $s$ jednakim rasporedom utakmica tijekom sezone, a samim time i tjedna, te jednakim brojem sati tjednoga trenažnog procesa.

Ukupan je broj sudionika 51, muškog su spola, prosječne dobi 20,27 $\pm 4,2$ godine (raspon od 16 do 33), tjelesne visine $183,01 \mathrm{~cm} \pm 6,27(171-195)$ te mase 80,42 $\mathrm{kg} \pm 12,69$ (60 - 132). Od ukupnog broja sudionika 30 je nogometaša (17 juniora i 13 seniora) te 21 rukometaš (osam juniora i 13 seniora). Nijedan sudionik u posljednjih šest mjeseci nije imao ozljedu koja bi ga udaljila od treninga ili natjecanja minimalno tri tjedna.

\subsection{Instrument}

Primijenjen je sustav procjene Funkcionalna procjena pokreta (FMS) koji se sastoji od sedam testova: duboki čučanj, prekorak, iskorak na liniji, test mobilnosti ramena, prednoženje iz ležanja na leđima, sklek i rotacijska stabilnost ${ }^{11}$. Ostvareni bodovi sportaša i komentari upisuju se u za to predviđenu tablicu.

Moguće su ocjene za svaki test od jedan do tri. Ako se kod sudionika pojavi bol u bilo kojem segmentu tijela, test se ocjenjuje ocjenom nula. Ocjenjivanje je jasno opisano i definirano u svakom od sedam testova. Za ocjenu tri sudionik mora izvesti test bez ijedne greške, kod ocjene dva uz minimalna odstupanja te kod ocjene jedan uz veća odstupanja ili gubitak balansa. Maksimalan je broj bodova $21^{1}$. Za samo testiranje potrebna je daska duljine $100 \mathrm{~cm}$, visine $5 \mathrm{~cm}$ te širine $10 \mathrm{~cm}$, zatim palica duljine $1 \mathrm{~m}$ te podesiva prepreka. Protokol provedbe i ocjenjivanja procjene FMS detaljno je opisan u literaturi ${ }^{5,6,9,14}$.

\subsection{Postupak}

Istraživanje je provedeno tijekom proljeća 2017. godine, a sudionicima je naglašeno da je njihovo sudjelovanje $u$ istraživanju dobrovoljno. U svakom od navedenih klubova sportaši seniorske $\mathrm{i}$ juniorske kategorije osobno su ispunili anamnestički upitnik koji čine osobni podaci sportaša, tjelesna visina, tjelesna masa, informacije o bavljenju sportom, dominantnoj ruci, dominantnoj i odraznoj nozi te podaci o postojanju ozljede koja je sportaša udaljila od treninga i natjecanja minimalno tri tjedna u posljednja tri odnosno posljednjih šest mjeseci. Period od tri tjedna oslanja se na prethodna istraživanja gdje je za kategorizaciju blažih od ozbiljnih ozljeda postavljen period prestanka treniranja od dvadeset $\mathrm{i}$ jedan dan ${ }^{12}$.

Nakon toga provedeno je pojedinačno testiranje svakog sportaša u prostorijama kluba uz standardiziranu opremu za testiranje. S obzirom na to da su testovi prilično zahtjevni, trebalo ih je raditi nakon kratkog zagrijavanja kako prilikom samog testiranja ne bi došlo do ozljede. Također, testiranje nije poželjno provoditi nakon treninga visokog intenziteta zbog smanjene koncentracije i umora sudionika ${ }^{1}$.

\section{Rezultati}

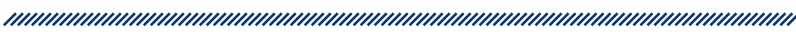
Osnovne antropometrijske i trenažne karakteristike sudionika ovog istraživanja prikazane su u tablici 1.

Tablica 1. Deskriptivna statistika osnovnih antropometrijskih i trenažnih karakteristika nogometaša $(N=30)$ i rukometaša $(N=21)$

\begin{tabular}{|c|c|c|c|c|}
\hline & \multicolumn{2}{|c|}{ Nogometaši } & \multicolumn{2}{|c|}{ Rukometaši } \\
\hline & $\mathrm{M}$ & SD & $\mathrm{M}$ & $\mathrm{SD}$ \\
\hline Dob & 19,73 & 3,25 & 21,05 & 4,91 \\
\hline Tjelesna visina $(\mathrm{cm})$ & 181,5 & 5,95 & 185,17 & 6,19 \\
\hline Tjelesna masa (kg) & 77,48 & 13,31 & 84,62 & 10,67 \\
\hline Indeks tjelesne mase $\left(\mathrm{kg} / \mathrm{m}^{2}\right)$ & 23,42 & 2,98 & 24,63 & 2,39 \\
\hline Godine treniranja & 12,47 & 2,99 & 11,95 & 5,24 \\
\hline
\end{tabular}


Između dviju promatranih skupina nije utvrđena statistički značajna razlika u dobi sudionika, kao ni u godinama treniranja, no rukometaši su značajno viši $(t=2,13$, $p=0,038)$ i teži $(t=2,04, p=0,047)$ od nogometaša, dok se po indeksu tjelesne mase značajno ne razlikuju $(t=1,547$, $p=0,128)$. U tablici 2 prikazane su frekvencije rezultata po pojedinim testovima FMS-a, dok su njihove aritmetičke sredine i standardne devijacije prikazane u tablici 3.

Najslabiji učinak pokazao se u rotacijskoj stabilnosti, gdje nijedan sudionik nije uspio u potpunosti udovoljiti zahtjevima i postići ocjenu tri. Sklek je test u kojem je najveći postotak nogometaša ocijenjen ocjenom tri (97\%), a potom slijedi iskorak na liniji sa $80 \%$ nogometaša s najvišom ocjenom. Najveći broj je rukometaša postigao ocjenu tri u prekoraku ( $86 \%)$, potom u skleku $(85 \%)$ te u dubokom čučnju ( $81 \%)$.
Jedina statistički značajna razlika u rezultatima nogometaša i rukometaša pokazala se za test iskoraka na liniji u kojem nogometaši postižu bolji rezultat $(t=3,202$; $p=0,002$ ).

Juniorske skupine ne razlikuju se međusobno statistički značajno po dobi, kao ni po godinama treniranja. Također, ni između dviju seniorskih skupina nema statistički značajne razlike po navedenim varijablama. Ako promatramo juniorsku u odnosu na seniorsku kategoriju bez obzira na vrstu sporta, one se značajno razlikuju u prekoraku ( $t=2,052 ; p=0,046)$, u čemu su bolji seniori ( $M=2,81$ u odnosu na juniore $M=2,52)$, te u mobilnosti ramena ( $t=2,615 ; p=0,012)$, u čemu su bolji juniori ( $M=2,00 \mathrm{u}$ odnosu na seniore $M=1,38)$. Također se juniori i seniori razlikuju po tjelesnoj masi $(t=3,039 ; p=0,004)$, visini $(t=3,47 ; p=0,001)$ i ITM-u

\section{Tablica 2. Frekvencije rezultata testova FMS-a nogometaša $(\mathbf{N}=\mathbf{3 0})$ i rukometaša $(\mathbf{N}=\mathbf{2 1})$}

\begin{tabular}{|c|c|c|c|c|c|}
\hline \multirow{2}{*}{ Test } & \multirow{2}{*}{ Ocjena } & \multicolumn{2}{|c|}{ Nogometaši } & \multicolumn{2}{|c|}{ Rukometaši } \\
\hline & & $\mathrm{N}$ & $\%$ & $\mathrm{~N}$ & $\%$ \\
\hline \multirow{3}{*}{$\begin{array}{c}\text { FMS } 1 \\
\text { duboki čučanj }\end{array}$} & 1 & 0 & 0 & 0 & 0 \\
\hline & 2 & 9 & 30 & 4 & 19 \\
\hline & 3 & 21 & 70 & 17 & 81 \\
\hline \multirow{3}{*}{$\begin{array}{l}\text { FMS } 2 \\
\text { prekorak }\end{array}$} & 1 & 0 & 0 & 1 & 4,5 \\
\hline & 2 & 13 & 43 & 2 & 9,5 \\
\hline & 3 & 17 & 57 & 18 & 86 \\
\hline \multirow{3}{*}{$\begin{array}{l}\text { FMS } 3 \\
\text { iskorak na liniji }\end{array}$} & 1 & 1 & 3 & 1 & 5 \\
\hline & 2 & 5 & 17 & 13 & 62 \\
\hline & 3 & 24 & 80 & 7 & 33 \\
\hline \multirow{4}{*}{$\begin{array}{c}\text { FMS } 4 \\
\text { mobilnost ramena }\end{array}$} & 0 & 1 & 3 & 0 & 0 \\
\hline & 1 & 15 & 50 & 12 & 57 \\
\hline & 2 & 5 & 17 & 5 & 24 \\
\hline & 3 & 9 & 30 & 4 & 19 \\
\hline \multirow{3}{*}{$\begin{array}{c}\text { FMS } 5 \\
\text { prednoženje iz ležanja na leđima }\end{array}$} & 1 & 0 & 0 & 0 & 0 \\
\hline & 2 & 7 & 23 & 5 & 24 \\
\hline & 3 & 23 & 77 & 16 & 76 \\
\hline \multirow{3}{*}{$\begin{array}{l}\text { FMS } 6 \\
\text { sklek }\end{array}$} & 1 & 0 & 0 & 0 & 0 \\
\hline & 2 & 1 & 3 & 3 & 15 \\
\hline & 3 & 29 & 97 & 18 & 85 \\
\hline \multirow{3}{*}{$\begin{array}{c}\text { FMS } 7 \\
\text { rotacijska stabilnost }\end{array}$} & 1 & 1 & 3 & 1 & 5 \\
\hline & 2 & 29 & 97 & 20 & 95 \\
\hline & 3 & 0 & 0 & 0 & 0 \\
\hline
\end{tabular}




\begin{tabular}{|c|c|c|c|c|}
\hline $\begin{array}{c}\text { Tablica 3. Aritmetičke sredine i standardne devijacije (SD) testova FMS-a i ukupnog rezultata } \\
\text { kod nogometaša (N = 30) i rukometaša (N = 21) }\end{array}$ \\
\hline \multirow{2}{*}{ Test } & \multicolumn{2}{|c|}{ Nogometaši } & \multicolumn{2}{c|}{ Rukometaši } \\
\hline Duboki čučanj & M & SD & M & SD \\
\hline Prekorak & 2,7 & 0,47 & 2,81 & 0,40 \\
\hline Iskorak na liniji & 2,57 & 0,50 & 2,81 & 0,51 \\
\hline Mobilnost ramena & 2,77 & 0,50 & 2,29 & 0,56 \\
\hline Prednoženje iz ležanja na leđima & 1,73 & 0,94 & 1,62 & 0,80 \\
\hline Sklek & 2,77 & 0,43 & 2,76 & 0,44 \\
\hline Rotacijska stabilnost & 2,97 & 0,18 & 2,86 & 0,36 \\
\hline FMS ukupno & 1,97 & 0,18 & 1,95 & 0,22 \\
\hline
\end{tabular}

$(t=2,056 ; p=0,045)$. Prosječna tjelesna masa juniora iznosi $75,32 \mathrm{~kg}$, a visina $180,20 \mathrm{~cm}$, dok su vrijednosti kod seniora $85,33 \mathrm{~kg}$ i $185,71 \mathrm{~cm}$.

Za detaljniju usporedbu četiri promatrane skupine koristili smo jednostavnu analizu varijance. S obzirom na veličinu uzoraka, Levenovim testom testirana je homogenost varijance koja je pokazala da za prvi, drugi, četvr$\mathrm{ti}$, šesti i sedmi test varijance nisu homogene $(p<0,01)$. Stoga je kao post-hoc test primijenjen Dunnett T3, koji je prikladan za primjenu u slučaju nehomogenih varijanci. ANOVA je pokazala značajnim samo iskorak na liniji $(F=3,480 ; p=0,023)$, no daljnja analiza u post-hoc postupku pokazala je statistički značajnom razliku i za prekorak i za iskorak na liniji: rukometaši seniori ostvarili su u prekoraku najbolji rezultat $(2,92)$ koji je statistički značajno različit od nogometaša juniora, a u iskoraku na liniji situacija je obrnuta: nogometaši juniori bili su najuspješniji $(2,82)$, što je značajno različito od rukometaša seniora.

Provjera povezanosti dobi i ukupnog rezultata na testu pokazala je nepostojanje značajne korelacije $(r=-0,22$; $p=0,128)$. Jedina značajna korelacija dobi i pojedinačnih testova dobivena je za mobilnost ramena $(r=-0,437$; $p=0,001)$ koja ukazuje na to da s dobi opada mobilnost

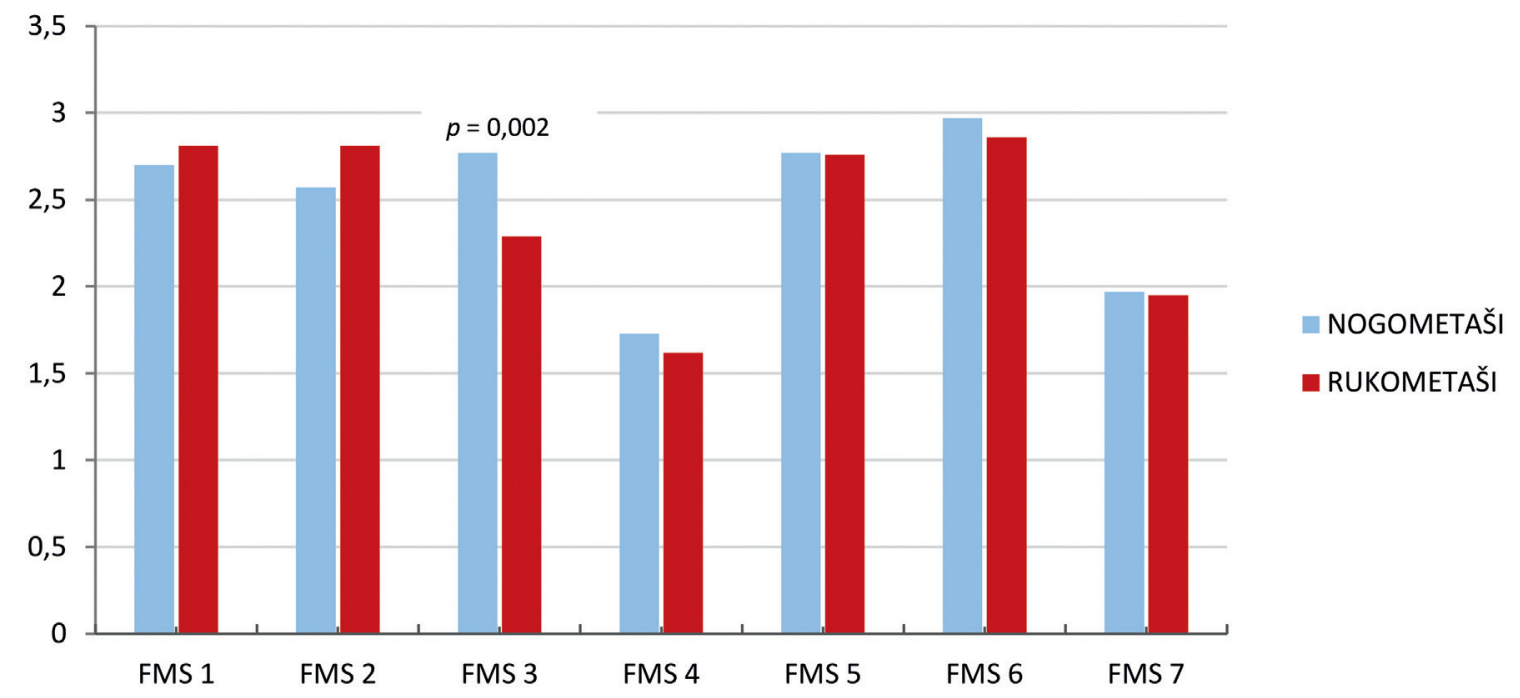




\begin{tabular}{|c|c|c|c|c|}
\hline $\begin{array}{c}\text { Tablica 4. Aritmetičke sredine za dob, godine treniranja te testove FMS-a i ukupnog rezultata } \\
\text { kod nogometaša seniora i juniora te rukometaša seniora i juniora }\end{array}$ \\
\hline & \multicolumn{2}{|c|}{ Nogometaši } & \multicolumn{2}{c|}{ Rukometaši } \\
\cline { 2 - 5 } & $\begin{array}{c}\text { juniori } \\
(\mathrm{N}=17)\end{array}$ & $\begin{array}{c}\text { seniori } \\
(\mathrm{N}=13)\end{array}$ & $\begin{array}{c}\text { juniori } \\
(\mathrm{N}=8)\end{array}$ & $\begin{array}{c}\text { seniori } \\
(\mathrm{N}=13)\end{array}$ \\
\hline Dob & 17,41 & 22,77 & 16,75 & 23,69 \\
\hline Godine treniranja & 10,53 & 15,00 & 7,88 & 14,46 \\
\hline Duboki čučanj & 2,76 & 2,62 & 2,63 & 2,92 \\
\hline Prekorak & 2,47 & 2,69 & 2,63 & 2,92 \\
\hline Iskorak na liniji & 2,82 & 2,69 & 2,25 & 2,31 \\
\hline Mobilnost ramena & 2,00 & 1,38 & 2,00 & 1,38 \\
\hline Prednoženje iz ležanja na leđima & 2,82 & 2,69 & 2,88 & 2,69 \\
\hline Sklek & 2,94 & 3,00 & 2,88 & 2,92 \\
\hline Rotacijska stabilnost & 1,94 & 2,00 & 1,88 & 2,00 \\
\hline FMS ukupno & 17,76 & 17,08 & 17,00 & 17,15 \\
\hline
\end{tabular}

ramena. Indeks tjelesne mase (ITM) pokazao se značajno povezanim s ukupnim rezultatom na FMS-u $(r=-0,296$; $p=0,035)$ te sa sljedećim testovima: duboki čučanj $(r=-0,287 ; p=0,041)$ i mobilnost ramena $(r=-0,282$; $p=0,045)$. Što je indeks tjelesne mase veći to je slabiji ukupni rezultat na testu, kao i u dubokom čučnju i mobilnosti ramena, iako korelacije nisu visoke.

S obzirom na prosječan ukupni rezultat FMS testa koji za cjelokupni uzorak iznosi 17,31, za skupinu nogometaša 17,46 , a za rukometaše 17,09 , možemo zaključiti da naši sudionici u prosjeku nisu u riziku za ozljedu. Sva tri rezultata statistički se značajno razlikuju od graničnog kritičnog rezultata, a to je 14 bodova. Za cijeli uzorak $t=14,621 ; p=0,000$, za nogometaše $t=11,192 ; p=0,000$, a za rukometaše $t=9,372 ; p=0,000$. Gledano pojedinačno, $7,8 \%$ sudionika ima rezultat jednak ili manji od 14 , što u FMS protokolu predstavlja granicu za rizik od ozljede.

\section{Diskusija}

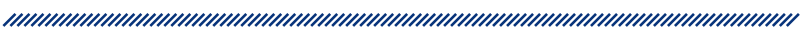

Cilj ovog istraživanja bio je usporediti dinamičku stabilnost rukometaša i nogometaša, pri čemu se kao metoda procjene primijenio test funkcionalne procjene pokreta FMS. Općenito, ukupni rezultat na FMS testu pokazuje kako obje skupine sportaša imaju dinamičku stabilnost bolju od ostatka populacije. Naime, prosječan ukupni rezultat FMS-a kod nogometaša i rukometaša iznosi 17,31 , dok je prema Schneidersu i sur. ${ }^{13}$ prosječna ocjena kod mladih aktivnih ljudi između 14,4 i 15,7. Takav je nalaz u skladu s očekivanjima jer je ipak riječ o aktivnim sportašima. Čini se da oba sporta dovode do bolje stabilnosti i mobilnosti lokomotornog sustava te se mogu preporučiti adolescentima kako bi poboljšali svoju dinamičku stabilnost. To potvrđuju i druga istraživanja, npr. Kiesela i suradnika ${ }^{12}$, koji su dobili rezultat za profesionalne igrače američkog nogometa 16,9.

Najslabiji rezultat obje su skupine sportaša postigle u podtestu mobilnosti ramena te rotacijskoj stabilnosti. U potonjem testu nijedan sudionik nije postigao maksimalnu ocjenu. Test rotacijske stabilnosti specifičan je u odnosu na ostalih šest; Cook i suradnici u priručniku za FMS $^{14}$ navode da je izrazito teško ostvariti maksimalnu ocjenu, komentirajući da je pri artikulaciji FMS protokola bilo upitno hoće li navedeni test biti u praktičnoj funkciji ukupnog rezultata za opću populaciju. Neki istraživači ${ }^{8,13}$ razmatrali su mogućnost da se u budućim verzijama FMS testa razmotri izuzimanje testa rotacijske stabilnosti. Minick i suradnici ${ }^{8}$ utvrdili su da svaki peti od ukupno 64 profesionalnih sportaša na tom testu dobiva ocjenu tri. Schneiders i suradnici ${ }^{13}$ proveli su istraživanje na uzorku od 209 aktivnih sportaša te ustanovili da je samo dvoje ispitanika ostvarilo maksimalan rezultat na navedenom testu. Autori zaključuju da test 
rotacijske stabilnosti ipak daje potencijal za objektivizaciju promjena u kontekstu asimetrične dinamičke stabilnosti trupa.

Nizak rezultat mobilnosti ramena očekivan je za rukometaše jer kod njih dolazi do karakteristične adaptacije pucačke ruke nazvanom glenohumeralnim deficitom unutarnje rotacije (engl. GRID), što je i karakteristično za bacačke odnosno pucačke sportove ${ }^{15}$.

Najbolji rezultat i nogometaši i rukometaši postižu u testu skleka, koji procjenjuje jakost i aktivaciju prednje stabilizacijske muskulature trupa, a što je moguće povezati sa snagom trupa i ramenog obruča naših ispitanika koji se natječu u nacionalnim ligama. Povećana segmentna jakost i snaga posredno je mogla dovesti do smanjenja fleksibilnosti struktura u području trupa i ramenog obruča, što je kod sudionika rezultiralo obrnuto proporcionalnim rezultatima FMS testa.

Pri usporedbi rukometaša i nogometaša nije nađena značajna razlika u ukupnom rezultatu na FMS-u, a gledajući pojedine testove, statistički značajna razlika pokazala se samo $u$ iskoraku na liniji, gdje su nogometaši ostvarili bolji rezultat od rukometaša. Možemo pretpostaviti da je posturalna adaptacija nogometaša biomehanički sukladnija zahtjevima tog podtesta. S obzirom na to da su rukometaši značajno teži i viši od nogometaša, dio objašnjenja možda leži i u toj razlici. Istraživanja provedena u drugim sportovima gdje se FMS primjenjivao kao metoda procjene stabilnosti i mobilnosti sportaša pokazuju kako rezultati variraju, što se može pripisati različitim zahtjevima svakog sporta, asimetriji tijekom učestalih kretnji te povećanoj stabilnosti ili mobilnosti pojedinih dijelova tijela sportaša, ovisno o vrsti sporta ${ }^{16,17}$, specifičnoj poziciji unutar pojedinog sporta $^{18,19}$ i dobnoj kategoriji ${ }^{20,21}$. Rezultati istraživanja ipak nisu ujednačeni; pojedini istraživači nisu utvrdili postojanje značajne razlike s obzirom na različita obilježja sportske aktivnosti, npr. između rukometaša prve i druge lige ili po pozicijama ${ }^{18}$.

Osim po vrsti sporta, proveli smo usporedbu i s obzirom na dobne kategorije. Usporedba juniora i seniora bez obzira na vrstu sporta pokazala je da su seniori značajno bolji u prekoraku, a juniori u mobilnosti ramena. Seniori su značajno i osjetno viši i teži od juniora te imaju i značajno veći ITM, što može jednim dijelom objasniti navedene razliku u mobilnosti ramena. Sljedeća analiza uspoređivala je dobne kategorije po sportovima. ANOVA je pokazala postojanje značajne razlike u podtestovima iskoraka na liniji te prekoraka: rukometaši seniori ostvarili su u prekoraku značajno bolji rezultat u odnosu na nogometaše juniore, dok je u iskoraku na liniji situacija obrnuta: nogometaši juniori bili su najuspješniji, što je značajno različito od rukometaša seniora. U ostalim testovima razlika nije značajna. Značajna razlika među dobnim kategorijama dobivena je u radu Loudona i suradnik ${ }^{20}$ na uzorku atletičara, gdje su mlađi ostvarili značajno bolje rezultate u iskoraku na liniji, prekoraku te skleku. Na temelju toga autori sugeriraju prilagodbu treninga kod starijih atletičara, gdje bi se više pažnje trebalo posvetiti vježbama stabilnosti i mobilnosti.

Korelacija dobi i ukupnog rezultata FMS-a niska je i neznačajna. Ovakav nalaz moguće je objasniti dobno vrlo selekcioniranim uzorkom jer je raspon dobi sudionika ograničen na životni period koji odlikuje vrhunac snage i tjelesne sposobnosti. Od pojedinačnih testova značajno je negativno povezana samo mobilnost ramena. Dobrić i Kiseljak ${ }^{21}$ utvrdili su negativnu povezanost dobi i rotacijske stabilnosti, ali s obzirom na to da je riječ o kvalitativno drukčijoj aktivnosti - profesionalnom baletu, rezultate nije opravdano direktno uspoređivati. Mogući razlog za rezultat smanjene mobilnosti ramena s dobi leži u specifičnoj posturalnoj prilagodbi ramenog obruča u oba sporta, paralelno s povećanjem mišićne mase. To možemo povezati sa sljedećim nalazom koji ukazuje na negativnu povezanost mobilnosti ramena $\mathrm{i}$ ITM-a. Osim mobilnosti ramena, s ITM-om su značajno negativno povezani ukupni rezultat na FMS testu i rezultati na testu dubokog čučnja. lako su te korelacije relativno niske, ipak indiciraju da u određenoj mjeri osobe s većim ITM-om postižu slabije rezultate na spomenutim testovima. To potvrđuje da iako su tjelesna snaga i mišićna masa važne u sportovima poput nogometa i rukometa, one nisu dostatne za specifične sportske izvedbe.

FMS test često se primjenjuje za procjenu rizika za ozljedu, pri čemu se uzima rezultat $\leq 14$ kao indikator loše kondicijske i tjelesne forme osobe. Bonazza i suradnici utvrdili su da rezultat $\leq 14$ predstavlja više nego dvostruko veći rizik za ozljede mišićno-koštanog sustava. Budući da je u našem istraživanju prosječan ukupni rezultat FMS testa za cjelokupni uzorak 17,31, za nogometaše 17,46 , a za rukometaše 17,09 , zaključujemo da sudionici u prosjeku nisu u riziku za ozljedu. Za usporedbu, prosječni rezultat na populaciji dječaka od šesnaest do sedamnaest godina iznosi 12,2 boda, a kod djevojčica 12,7 bodova ${ }^{22}$, odnosno u istraživanju koje je proveo Karuc ${ }^{23}$ prosječni rezultat iznosi 12,2 boda. Autori naglašavaju kako su adolescenti ostvarili niske rezultate i pripadaju rizičnoj skupini, što potencijalno može ugroziti njihov zdravstveni status i kvalitetu života, $\mathrm{s}$ obzirom na smanjenu stabilnost i posturalnu kontrolu 
tijela. Za razliku od toga, Anderson i suradnici ${ }^{24}$ utvrdili su kako srednjoškolci koji se bave atletikom ostvaruju rezultat u dinamičkoj stabilnosti veći od 14 , dok srednjoškolke ostvaruju nešto niži rezultat. I kod drugih sportaša slična je situacija - primjerice, Slodownik i suradnici ${ }^{18}$ utvrdili su kako kod rukometaša ne postoji visok rizik od ozljede.

S obzirom na to da asimetrija u snazi i fleksibilnosti te loš balans ukazuju na veću mogućnost ozljede, FMS se pokazao kao skup testova koji uključuje procjenu svega navedenog ${ }^{11}$. Yeung i suradnici ${ }^{25}$ potvrdili su da testovi mobilnosti, propriocepcije, snage te modificirani FMS mogu biti dobri prediktori ozljeda kod profesionalnih nogometaša.

Za razliku od ukupnog rezultata, Hotta i suradnici ${ }^{26}$ smatraju da su duboki čučanj i prednoženje učinkovitiji za procjenu rizika ozljeda trkača. Kiesel i suradnici ${ }^{27}$ naglašavaju da je duboki čučanj najbolji prediktor niskoga ukupnog rezultata: sportaši koji su u prije intervencije imali ocjenu jedan kod dubokog čučnja imali su pet puta veću vjerojatnost da nakon intervencije ostvare rezultat niži od graničnog. Naše istraživanje nije potvrdilo važnost testa dubokog čučnja. Najveću korelaciju $s$ ukupnim rezultatom ima iskorak na liniji $(r=0,622$; $p=0,000)$, a potom test mobilnosti ramena $(r=0,616$; $p=0,000)$, dok je duboki čučanj tek na trećem mjestu $(r=0,536 ; p=0,000)$. Zanimljivo je da učinak u testu prekoraka uopće nije značajno povezan s ukupnim rezultatom ( $r=0,271 ; p=0,054)$, što ukazuje na specifičnost zahtjeva tog testa u odnosu na ostale.

Općenito, autori preporučuju FMS kao pouzdanu metodu procjene dinamičke stabilnosti sportaša u pojedinom sportu. Navedeno može koristiti terapeutima koji rade u sportu kako bi smanjili mogućnost ozljeđivanja ${ }^{27}$. Međutim, neki autori upozoravaju da nije opravdano primjenjivati FMS kao jedinu metodu procjene rizika za ozljedu kod specifičnih skupina, primjerice kod sportaša srednjoškolaca ${ }^{28}$. FMS može služiti kao mjera evaluacije individualnih i ciljanih treninga te kao indeks kvalitete sportaševe izvedbe ${ }^{18}$. FMS nije samo dobra metoda procjene nego i dobar skup vježbi koje djeluju na poboljšanje dinamičke stabilnosti, a samim time i na prevenciju ozljeđivanja.

Ograničenje provedenog istraživanja prvenstveno je nedovoljno velik uzorak sudionika, s obzirom na to da je istraživanje provedeno u samo dva kluba. Nakon uočenih niskih rezultata na pojedinim testovima preporučuje se upotreba specifičnijih testova koji bi ukazali na postojeće i potencijalne probleme sportaša.
FMS kao instrument procjene dinamičke stabilnosti preporučuje se jer se pokazao dovoljno osjetljivim i jednostavnim za primjenu. Potrebnu opremu lako je samostalno napraviti te ne zahtijeva veće financijske izdatke, dok je edukacija o načinu ocjenjivanja vrlo detaljno opisana te lako primjenjiva. Testovi su prilično zahtjevni za izvedbu te nam se čine prikladnima upravo za testiranje sportaša.

U daljnjim istraživanjima preporučuje se uključivanje većeg broja sudionika kako bi rezultati bili relevantniji te primjena specifičnih testova koji bi ukazali na potencijalne i postojeće probleme sportaša.

\section{Zaključak}

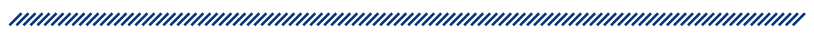

Usporedba nogometaša i rukometaša pokazala je da nema statistički značajne razlike u njihovoj dinamičkoj stabilnosti izraženoj kao ukupni rezultat na FMS testu. Statistički značajnom pokazala se jedino razlika u iskoraku na liniji, gdje su nogometaši ostvarili bolji rezultat u odnosu na rukometaše.

Između seniora i juniora u istom sportu nema značajne razlike kako u testovima FMS-a tako ni u ukupnom rezultatu, ali su juniori značajno bolji od seniora u mobilnosti ramena, dok su seniori bolji u prekoraku. Značajne razlike postoje i između nogometaša juniora u odnosu na rukometaše seniore u prekoraku i iskoraku na liniji: u prekoraku su značajno bolji rukometaši seniori, a u iskoraku na liniji nogometaši juniori.

Korelacija dobi i ukupnog rezultata na FMS testu nije statistički značajna, a od pojedinačnih testova samo mobilnost ramena značajno opada s dobi. Što je ITM veći to je slabiji ukupni rezultat na testu, kao i u dubokom čučnju i mobilnosti ramena, iako korelacije nisu visoke.

Nogometaši i rukometaši ne pripadaju skupini s povećanim rizikom od ozljeda s obzirom na to da su ostvarili značajno veći rezultat od kritične granice 14 bodova. 


\section{Literatura}

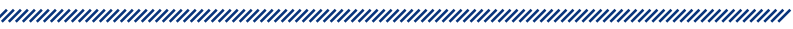

1. Džeko D, Milanović M. Funkcionalna procjena pokreta. Kondicijski trening. 2010; 8(2): 23-27.

2. Boyle M. Functional training for sports. Champaign, IL: Human Kinetics; 2004.

3. Kendall FP, McCreary EK, Provance PG, Rodgers MM, Romani WA. Muscles, Testing and Function with posture and pain. Baltimore, MD: Lippincott Williams \& Wilkins; 2005.

4. Sahrmann SA. The human movement system: our professional identity. Phys Ther. 2014; 94(7):1034-42.

5. Cook G, Burton L, Hoogenboom B. Pre-participation screening: the use of fundamental movements as an assessment of function-part 1. N Am J Sports Phys Ther. 2006; 1(2):62-72.

6. Cook G, Burton L, Hoogenboom BJ, Voight M. Functional movement screening: the use od fundamental movements as an assessment of function - part 2. Int J Sports Phys Ther. 2014; 9(4):549-63.

7. Bonazza NA, Smuin D, Onks CA, Silvis ML, Dhawan A. Reliability, validity, and injury predictive value of the functional movement screen: a systematic review and metaanalysis. Am J Sports Med. 2017; 45(3):725-732.

8. Minick KI, Kiesel KB, Burton L, Taylor A, Plisky P, Butler RJ. Interrater reliability of the functional movement screen. J Strength Cond Res. 2010; 24(2):479-486.

9. Teyhen DS, Shaffer SW, Lorenson CL, Halfpap JP, Donofry DF, Walker MJ, Dugan JL, Childs JD. The functional movement screen: a reliability study. J Orthop Sports Phys Ther. 2012; 42(6):530-540.

10. Smith CA, Chimera NJ, Wright NJ, Warren M. Interrater and intrarater reliability of the functional movement screen. J Strength Cond Res. 2013; 27(4):982-987.

11. Cook G, Burton L, Hoogenboom BJ, Voight M. Functional movement screening: the use od fundamental movements as an assessment of function - part 1. Int J Sports Phys Ther. 2014; 9(3):396-409.

12. Kiesel K, Plisky PJ, Voight ML. Can serious injury in professional football be predicted by a preseason functional movement screen? N Am J Sports Phys Ther. 2007; 2(3):147-152.

13. Schneiders AG, Davidsson Å, Hörman E, Sullivan SJ. Functional movement screen ${ }^{\mathrm{TM}}$ normative values in a young, active population. Int J Sports Phys Ther. 2011; 6(2):75-82.

14. Cook G, Burton, L, Kiesel K, Rose G, Byrant MF, Torine J. Movement: Functional movement systems: Screening, assessment, corrective strategies. Santa Cruz, CA: On Target Publications; 2010.

15. Almeida GP, Silveira PF, Rosseto NP, Barbosa G, Ejnisman $B$, Cohen $M$. Glenohumeral range of motion in handball players with and without throwing-related shoulder pain. J Shoulder Elb Surg. 2013; 22(5):602-607.
16. Kovačić G. Razlike u funkcionalnom pokretu između atletičara bacača, skakača i sprintera. Diplomski rad. Zagreb: Sveučilište u Zagrebu; Kineziološki fakultet; 2016.

17. Ban M. Funkcionalna procjena s ciljem utvrđivanja asimetrije u opsegu i kvaliteti pokreta kod odbojkašica HAOK „Mladost”'. Diplomski rad. Zagreb: Sveučilište u Zagrebu; Kineziološki fakultet; 2016.

18. Slodownik R, Ogonowska-Slodownik A, Morgulec-Adamowicz N, Targosinski P. Fundamental movement patterns and potential risk on injuries in 1st and 2 nd division Polish handball players. Trends in Sport Sciences. 2014; 3(21):145-151.

19. Kiesel KB, Butler RJ, Plisky PJ. Prediction of injury by limited and asymmetrical fundamental movement patterns in American football players. J Sport Rehabil. 2014; 23(2):88-94.

20. Loudon JK, Parkerson-Mitchell AJ, Hildebrand LD, Teague $C$. Functional movement screen scores in a group of running athletes. J Strength Cond Res. 2014; 28(4):909913.

21. Dobrić D, Kiseljak D. Physiotherapy Assessment of Postural Stability and Mobility at Professional Ballerinas. Physiotherapia Croatica. 2015; 13(Suppl. 1):30-33.

22. Jelčić M. Funkcionalnost pokreta kod hrvatskih adolescenata: spolne razlike. Diplomski rad. Zagreb: Sveučilište u Zagrebu; Kineziološki fakultet; 2017.

23. Karuc J. Funkcionalni pokret kod šesnaestogodišnjaka: deskriptivna studija. Diplomski rad. Zagreb: Sveučilište u Zagrebu; Kineziološki fakultet; 2016.

24. Anderson BE, Neumann ML, Bliven KC. Functional movement screen differences between male and female secondary school athletes. J Strength Cond Res. 2015; 29(4):1098-1106.

25. Yeung J, Cleves A, Griffiths H, Nokes L. Mobility, proprioception, strength and FMS as predictors of injury in professional footballers. BMJ open Sport Exerc Med. 2016; 2(1):e000134.

26. Hotta T, Nishiguchi S, Fukutani N, Tashiro Y, Adachi D, Morino S, Shirooka H, Nozaki Y, Hirata H, Yamaguchi M, Aoyama T. Functional movement screen for predicting running injuries in 18-to 24-year-old competitive male runners. J Strength Cond Res. 2015; 29(10):2808-2815.

27. Kiesel K, Plisky P, Butler R. Functional movement test scores improve following a standardized off-season intervention program in professional football players. Scand J Med Sci Sports. 2011; 21(2):287-292.

28. Bardenett SM, Micca JJ, DeNoyelles JT, Miller SD, Jenk DT, Brooks GS. Functional Movement Screen normative values and validity in high school athletes: can the FMS ${ }^{\mathrm{TM}}$ be used as a predictor of injury?. Int J Sports Phys Ther. 2015; 10(3):303-308. 


\section{COMPARISON OF DYNAMIC STABILITY BETWEEN FOOTBALL AND HANDBALL PLAYERS}

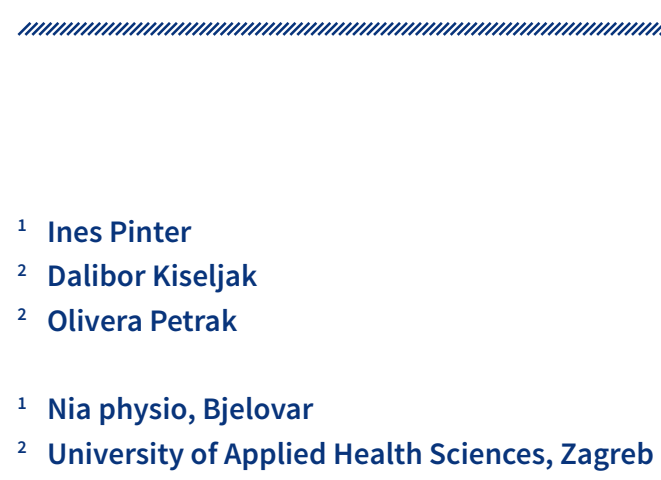

IIIIIIIIIII (IIIIIXIM

\author{
1 Ines Pinter \\ 2 Dalibor Kiseljak \\ 2 Olivera Petrak \\ 1 Nia physio, Bjelovar \\ 2 University of Applied Health Sciences, Zagreb
}

\section{Abstract}

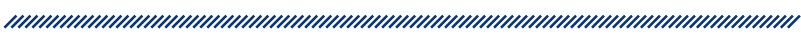

In order to perform high-intensity training, an athlete should have optimal posture, balance, equally distributed muscle strength and flexibility on the left and right, as well as the front and back of the body, i.e. good stability and mobility.

The objective of this study is to compare dynamic stability between football and handball players using Functional Movement Screening (FMS). FMS includes seven different tests that assess the mobility and stability insufficiency and asymmetry, and has shown as a reliable predictor of injury risk. The authors also wanted to investigate differences in FMS scores according to age range, and between the two sports. Furthermore, we wanted to test if age and participants' body mass index (BMI) were correlated with dynamic stability expressed as total FMS score.

The study was conducted in FC Bjelovar and HC Bjelovar, on a sample of 51 athletes, whose average age was 20.27 years (range 16-33), height $183.01 \mathrm{~cm}$ (171-195) and weight $80.42 \mathrm{~kg}$ (60-132). The sample comprised of 30 football players ( 17 juniors and 13 seniors) and 21 handball players (8 juniors and 13 seniors).

The only statistically significant difference between football and handball players was found in the in-line lunge test, where football players achieved a higher score. There was no significant difference in any test between junior and senior athletes of both sports. ANOVA showed significant difference between senior handball and junior football players in the hurdle step and in-line lunge test.

There was no significant correlation between age and total FMS score, but the result of the shoulder mobility test had a significant negative correlation with age. BMI showed a significant negative correlation with the total FMS score, deep squat and shoulder mobility test, but these correlations were rather low.

Football and handball players did not prove the profile associated with greater injury risk. The FMS is recommended as a dynamic stability assessment tool because of its reliability, sensitivity and ease of use.

Keywords: FMS, stability, mobility, football, handball 